\title{
Effect of Drying Technique on Physical Quality and Anti-Inflammatory Activity of Wild Betel Leaves (Piper Sarmentosum Roxb. Ex Hunter) Extract
}

\author{
FAHLENI*, SYARIFAH RAMADHANI, YUSLIA NOVIANI.
}

\author{
Faculty of Pharmacy, University of Pancasila, Jakarta, Indonesia
}

Diterima 2 Januari 2018, Disetujui 14 Februari 2018

\begin{abstract}
Wild betel leaves (Piper sarmentosum Roxb. ex. Hunter) contain flavonoids and alkaloids that have anti-inflammatory activity. Processing thick extract into a dry extract is required to determine the appropriate dose and increase the homogeneity. The purpose of tahhis study was to determine the effect of drying method to physical properties of dried powder and its antiinflammatory activity. Thick extract was dried using maltodextrin and lactose as adsorbents with concentrations of extract-adsorbent ratio $1: 1,1: 2$ and $1: 3$. Method of drying were freeze drying and adsorbent. The evaluation results based on organoleptic dried powder, water content and flow properties. The water content of dried powder which is dried by freeze drying is smaller than that of the adsorbent. Organoleptic and flow properties of freeze dried powder results were also better. The best dried extract in each method tested its anti-inflammatory activity using Bovine Serum Albumine (BSA) denaturation methods. The results showed that the anti-inflammatory activity of dried extract of freeze drying (extract - maltodextrin $1: 3$ ) had higher activity with $\mathrm{IC}_{50} 551.79 \mathrm{ppm}$ compared to dried extract with adsorbent (extract maltodextrin $1: 3$ ) with $\mathrm{IC}_{50}$ of $598.30 \mathrm{ppm}$.
\end{abstract}

Keywords: Piper sarmentosum Roxb. ex Hunter, anti-inflammatory activity, freeze drying, adsorbent.

\begin{abstract}
Abstrak: Daun sirih kaduk (Piper sarmentosum Roxb. Ex. Hunter) mengandung flavonoid dan alkaloid yang memiliki aktivitas anti inflamasi. Proses pengeringan ekstrak kental menjadi ekstrak kering bertujuan untuk mendapatkan dosis yang tepat dan meningkatkan homogenitas. Tujuan penelitian ini adalah untuk mengetahui pengaruh metode pengeringan terhadap sifat fisik ekstrak kering dan aktivitas antiinflamasinya. Ekstrak kental dikeringkan menggunakan maltodekstrin dan laktosa sebagai adsorben tunggal masing-masing dengan konsentrasi rasio ekstraksi - adsorben $1: 1,1: 2$ dan $1: 3$. Metode pengeringan yang digunakan adalah pengeringan beku dan adsorben. Evaluasi yang dilakukan terhadap ekstrak kering adalah sifat organoleptik, kandungan air dan sifat alir. Hasil menunjukkan kandungan air dari ekstrak kering menggunakan pengering beku lebih rendah dibandingkan kandungan air dari ekstrak yang dikeringkan menggunakan adsorben saja. Sifat organoleptik dan sifat alir ekstrak kering dari pengeringan dengan menggunakan pengering beku juga lebih baik. Ekstrak kering terbaik yang diperoleh dari setiap metode pengeringan diuji aktivitas anti-peradangannya menggunakan metode denaturasi Bovine Serum Albumine (BSA). Hasil pengujian menunjukkan bahwa aktivitas antiinflamasi ekstrak kering dengan menggunakan pengering beku (ekstrak - maltodekstrin $1: 3$ ) memiliki aktivitas yang lebih tinggi dengan $\mathrm{IC}_{50}$ sebesar $551,79 \mathrm{ppm}$ dibandingkan ekstrak kering menggunakan adsorben (ekstrak - maltodekstrin $1: 3$ ) dengan IC50 598.30 ppm.
\end{abstract}

Kata kunci: Piper sarmentosum Roxb. ex Hunter, aktivitas anti inflamasi, freeze drying, adsorbent.

\footnotetext{
* Penulis korespondensi, Hp. 08127676910

e-mail: fahleni_asril@yahoo.com
} 


\section{INTRODUCTION}

PIPER sarmentosum (Piperaceae) is plant that can be found in tropical and subtropical regions and is used as food and traditional medicine. Kaduk leaves contains secondary metabolite compounds such as amides, alkaloids, flavonoids, pyrones, dihydrochalcones, phenylpropanoids, lignans and neolignans. Traditionally, the whole plants is used in various forms such as crude powders and aqueous extract for releave toothache, headache, asthma, joint pain, reduce fever in influenza, expectorant, and carminative $^{(8)}$.

Hussain, 2012 proves that this plant has pharmacological activities such as anti-cancer, hypoglycemic, anti-tuberculosis, antioxidant, antimalarial, antibacterial, antifungal, and antiinflammatory. Methanol extract of betel leaves at 50,100 and $250 \mathrm{mg} / \mathrm{kg}$ had anti-inflammatory effect with inhibition of $8.6,18.6$ and $24.7 \%$ proven to decrease the volume of edema in rat's $\mathrm{leg}^{(2)}$. Some of the components of betel leaves are heat sensitive such as ascorbic acid, flavonoids, tannins and other phenol groups ${ }^{(10)}$.

The drying process that can be done is freeze drying and addtion the adsorbent. Freeze drying method has several advantages over other methods such as more stable because using low temperatures and reduce the enzymatic reaction. In addition, the freeze-drying method may also produce a porous end product thereby increasing the surface area of the material and increasing solubility ${ }^{(6)}$. While the method of addition of adsorbent on drying with oven can be done easily and save production cost. In this research, variation of maltodextrin and lactose as adsorbent were used with concentration of variations extract-adsorbent $1: 1 ; 1: 2$, and $1: 3$ respectively.

The purpose of adding different types of adsorbents and variations of these concentrations is to study the effect on the physical properties of the resulting dried extract.

\section{MATERIAL AND METHODS}

MATERIAL. Wild betel leaves (Piper Sarmentosum Roxb. Ex Hunter) obtained from Balitro Pascapanen Bogor and determined in Herbarium Bogoriense
Indonesian Institutes of Science (LIPI) Cibinong West Java, maltodextrin, lactose, Bovine Serum Albumin (Sigma Aldrich), Tris base (Sigma Aldrich), ethanol

METHODS. Collection and Preparation of Samples. Approximately $2 \mathrm{~kg}$ of mature Piper sarmentosum leaves samples were collected from Pasca Panen Balitro. The wet weight and dry weights were recorded and then the samples were ground using a blender into powder form.

Extraction. Ground samples in powder form were macerated with ethanol $70 \%$ at room temperature for 24 hours at atime, 6 hours with kinetic and this process was repeated twice. Filtrates were then evaporated under a reduced pressure at $40{ }^{\circ} \mathrm{C}$ using a rotary evaporator.

Drying Process and Evaluation of Dried Powder. Thick extract were dried using using two ways: freezing drying and adsorbent by evaporation. Maltodextrin and lactose with variation of concentration of each with thick extract-adsorbent ratio $1: 1,1: 2,1: 3$. Evaluation of dried powder including organoleptic, water content and flow properties.

Anti-Inflammatory Activity. The best dried extract of each method based on its physical properties were tested its inflammatory activity through protein coagulation of Bovine Serum Albumin (BSA).

\section{RESULTS AND DISCUSSION}

Freeze drying with maltodextrin adsorbent material at all concentrations produced brown dry powder, rather hygroscopic, typical aromatic smell and bitter taste. While lactose-the extract in concentration ratio of $1: 1$ and $1: 2$ produced extract that is still wet and very hygroscopis. Therefore the freeze drying with lactose adsorbents at $1: 1$ and 1 $: 2$ concentrations could not be tested for their flow properties. At a concentration of $1: 3$ the resulting powder is dry brown, aromatic typical smell and bitter taste. Drying methods with maltodextrin-the extract and lactose-extract in the concentration ratio of $1: 1$ and 1: 2 produced wet and sticky powders. Therefore it can not be tested its flow properties. While with maltodextrin and lactose adsorbent at concentration $1: 3$ brown powder produced dry, aromatic typical smell and bitter taste (Table 1). 
Table 1. Result of water content of dried powder.

\begin{tabular}{|c|c|c|c|c|}
\hline No & Methods of drying & Adsorbent & $\begin{array}{c}\text { Ratio extract- } \\
\text { adsorbent }\end{array}$ & $\begin{array}{c}\text { Water } \\
\text { content }(\%)\end{array}$ \\
\hline \multirow{6}{*}{1.} & \multirow{7}{*}{ Freeze Drying } & \multirow{4}{*}{ Maltodekstrin } & $1: 1$ & 5,88 \\
\hline & & & $1: 2$ & 5,75 \\
\hline & & & $1: 3$ & 4,53 \\
\hline & & & $1: 1$ & 7,43 \\
\hline & & \multirow[t]{3}{*}{ Lactose } & $1: 2$ & 5,46 \\
\hline & & & $1: 3$ & 4,62 \\
\hline & & & $1: 1$ & 8,69 \\
\hline \multirow{5}{*}{2.} & \multirow{5}{*}{ Adsorbent } & \multirow[t]{3}{*}{ Maltodextrin } & $1: 2$ & 7,20 \\
\hline & & & $1: 3$ & 6,99 \\
\hline & & & $1: 1$ & 8,65 \\
\hline & & \multirow[t]{2}{*}{ Lactose } & $1: 2$ & 7,36 \\
\hline & & & $1: 3$ & 6,94 \\
\hline
\end{tabular}

Water content of dried extract fullfilled the requirement. The result of flow properties of both dried powder did not meet the requirements because they were very cohesive so they need to be granulated to improve its flow properties. The results of dried extract flow properties are proportional to the concentration of the drying agent used. The smaller the concentration of the adsorbent, the worse the flow properties (Table 2).

\begin{tabular}{|c|c|c|c|c|}
\hline $\begin{array}{l}\text { Methods of } \\
\text { drying }\end{array}$ & Adsorbent & $\begin{array}{c}\text { Extract- } \\
\text { adsorbent } \\
\text { ratio }\end{array}$ & $\begin{array}{c}\text { Flow } \\
\text { rate }(\mathrm{g} / \mathrm{sec})\end{array}$ & $\begin{array}{c}\text { Angle of Repose } \\
\left({ }^{0}\right)\end{array}$ \\
\hline \multirow[t]{6}{*}{ Freeze Drying } & Maltodextrin & $1: 1$ & $0,51 \pm 0,04$ & $38,21 \pm 0,85$ \\
\hline & & $1: 2$ & $2.33 \pm 0.20$ & $37,21 \pm 1,40$ \\
\hline & & $1: 3$ & $2,48 \pm 0,90$ & $23,48 \pm 2,23$ \\
\hline & Lactose & $1: 1$ & . & . \\
\hline & & $1: 2$ & - & . \\
\hline & & $1: 3$ & $1,80 \pm 0,20$ & $35,22 \pm 0,72$ \\
\hline \multirow[t]{6}{*}{ Adsorbent } & Maltodextrin & $1: 1$ & - & . \\
\hline & & $1: 2$ & . & . \\
\hline & & $1: 3$ & $1,74 \pm 0,16$ & $21,64 \pm 0,32$ \\
\hline & Lactose & $1: 1$ & . & . \\
\hline & & $1: 2$ & - & . \\
\hline & & $1: 3$ & $0,88 \pm 0,04$ & $20,96 \pm 1,45$ \\
\hline
\end{tabular}

Freeze drying has high efficiency in moisture removal and maintains bioactive components. During the freeze-drying process, ice crystals develop within the tissue matrix and removal of moisture content causes the tissue to become more brittle. The lower the moisture content, the greater the rupture of the cell structure, which may lead to higher solvent extraction efficiency of anti-inflammatory compounds with $\mathrm{IC}_{50}$ of $551.79 \mathrm{ppm}$ compared to dried extract using adsorbent (extract - maltodextrin $1: 3$ ) with $\mathrm{IC}_{50}$ of $598.30 \mathrm{ppm}^{(3)}$.

\section{CONCLUSION}

In general, the freeze drying method results dried extract in smaller water content and increased the flow rate and angle of repose of the extract. The anti-inflammatory activity of dried extract of freeze drying (extract - maltodextrin $1: 3$ ) with $\mathrm{IC}_{50}$ of $551.79 \mathrm{ppm}$ compared to dried extract using adsorbent (extract - maltodextrin $1: 3$ ) with $\mathrm{IC}_{50}$ of $598.30 \mathrm{ppm}$.

\section{ACKNOWLEDGEMENTS}

This work was funded by Faculty of Pharmacy, University of Pancasila for Hibah Insentif in 2017.

\section{REFERENCES}

1. Hussain K, Ismail Z, Sadikun A, Ibrahim P. Original Article Bioctive Markers Based Pharmacokinetic Evaluation of Extracts of a Traditional Medicinal Plant, Piper sarmentosum. Evidance-Based Compl Alternative Med. 2009;201(1):1-7.

2. Hussain K, Hashmi FK, Latif A, Ismail Z, Sadikun A. A review of the literature and latest advance in research of Piper sarmentosum. Pharm Biology. 2012;50(8):1045-52.

3. Hossain, M.B., Barry-Ryan, C., Martin-Diana, A.B. \& Brunton, N.P. 2010. Effect of drying method on the antioxidant capacity of six Lamiaceae herbs. Food Chemistry 1: 85-91.

4. Indrawati T, Rosliani S. Pembuatan Granul Ekstrak Kerimg Buah Mahkota Dewa dengan Variasi Konsentrasi Adsorben. Jurnal Ilmu Kefarmasian. 2010.1(1):10-18.

5. Parikh DM. Handbook of Pharmaceutical Granulation Technology. Marcel Dekker Inc. New York: 1995. h.7,156.

6. Parhusip A. Pengeringan Beku dan Pengaruhnya terhadap Produk buah-buahan. Majalah Ilmiah Media Unika. Sumatera Utara: Universitas Katholik Saint Thomas; 1997. h.76-9

7. Rautela S, Badola A, Ritesa. The Lyophilization Process for The Development of Unstable Drug; Indo Am. J. Pharm. Sci, 2015;2(9);1339-41

8. Ridtitid W, Ruangsang P, Reanmongkol W, Wongnawa M. Studies of the anti-inflammatory and antipyretic activities of the methanolic extract of Piper sarmentosum Roxb. leaves in rats. Songklanakarin J Sci Technol 2007; 29(6):1519-26.

9. Rahman SFSA, Sijam K, Omar D. Piper sarmentosum Roxb: A Mini Review of Etnobotany, Phytochemistry and Pharmacology. J Anal Pharmacol Res. 2016;2(5):13

10. Soptijah P, Jacoeb AM, Rachmania D. Phytochemistry of the genus Piper. Elsevier Sci. 1997.46(4):597-673. 